\title{
Research on Rural Financing in China with Reference to Village and Township Banks: An Overview
}

\author{
Bal Ram Duwal ${ }^{1} \&$ Shao Yan Sun $^{2}$ \\ ${ }^{1}$ College of Economics, Jilin University, Changchun, PR China \\ ${ }^{2}$ Research Center for China Public Sector Economy, Jilin University, Changchun, PR China \\ Correspondence: Shao Yan Sun, PhD Supervisor, Research Center for China Public Sector Economy, Jilin \\ University, Qianjin Street 2699, Changchun 130012, PR China. E-mail: jlcssy@sina.com
}

Received: November 22, 2012 Accepted: January 10, $2013 \quad$ Online Published: January 25, 2013
$\begin{aligned} & \text { doi:10.5539/ijbm.v8n4p75 } \\ & \text { URL: http://dx.doi.org/10.5539/ijbm.v8n4p75 }\end{aligned}$

The research is funded by Jilin University '985 Construction'.

\begin{abstract}
The problem of rural financing is one of the major challenges to the emerging China. It is challenging for government authorities to provide adequate financial resources and access to financial institutions in rural agricultural areas to farmer households. The development of Village and Township Banks (VTBs) has remarkably increased since 2008 but the deposit collection of VTBs is comparatively weaker than the loan disbursement. Despite of facing numerous challenges, establishing within the framework of new-type financial institutions is playing a significant role for the development of agricultural sector. For the sustainable development of VTBs, VTBs should set up staff and member incentive system, introduce innovative financial products; and strengthen the agricultural insurance system. The cooperation between VTBs and the other rural financial institutions should be developed to meet short-term rural financing gap and to strengthen the institutional capacity of VTBs. The government's support in policy formulation and financial assistance is essential and the local government intervention should be discouraged. An autonomously functioning financial institution can enhance the sustainable development of rural households' income, in particular, and the agricultural sector, in general.
\end{abstract}

Keywords: rural finance, rural financial institutions, village and township banks, financial inclusion

\section{Introduction: Rural Financial System in China}

Rural finance is a major part of overall China's financial system, where $52 \%$ of the entire population still lives in the rural areas. In China there is a huge gap between urban and rural household income. The average income of urban residents was 3.13 times higher than the rural residents in the year 2011(Xinhua, 2012). The per capita disposable income of rural residents stood at Renminbi (Here after RMB) 6,977 whereas the urban residents' stood at RMB 21,810. By the end of 2011, 48.73 percent of the total population (1.347 billion) lived in rural areas (National Bureau of Statistics, 2012). However, rural population decreased by 14.56 million and stood at 656.56 million in the same period. So, developing the rural financial system is an important part in the effort of building a socialist new countryside. It is also a long-term endeavor to promote a balanced economic development of the urban and rural China as well as Eastern and Western China.

Currently, the four types of formal financial institutions: Policy-based financial institutions, Commercial-based financial institutions, Cooperative-based financial institutions, and New-type rural financial institutions are active in rural China. Historically, rural finance started after the independence of the Agricultural Bank of China (Here in after ABC) from the People's Bank of China (Here in after PBOC) in February 1979. The former is a policy-based financial institution specially focused in agricultural and rural development. The rural financial system in China mainly consists of Agricultural Development Bank of China (Here in after ADBC), ABC, Postal Savings Bank of China (Here in after PSBC), Rural Credit Cooperatives (Here in after RCCs), Rural Cooperatives Bank, Rural Commercial Bank and various new financial institutions. The ADBC is the only policy based financial institution. As a regulatory body, the China Banking Regulatory Commission (Here in after CBRC) and PBOC exists in China's rural financial system. These rural financial institutions are providing rural 
financial services such as saving, loan, remittance, insurance, futures, securities etc. For details see the graph attached in appendix 1.

\title{
1.1 The Existing Problems in Rural Finance 'San Nong'
}

The Third National Financial Work Conference held in 2007 made some decisions to establish and improve a multi-tired, extensive and sustainable rural financial system tailored to the need of the development of agriculture, rural areas and farmers which is commonly known as 'San Nong' in Chinese. The country is repeatedly stressing on financial institutions to support 'San Nong'. The four big banks (Bank of China-BOC, Agricultural Bank of China-ABC, Industrial and Commercial Bank of China-ICBC and China Construction Bank-CCB) withdrew the investment below county level due to the high risk, low benefits and low return in investment. Finally, only RCCs were left there to provide loan to the farmers but RCCs were capable to provide only around RMB 500 credit per household (Sun, 2008). Some urban and commercial banks also transferred the fund collected in the country to big cities and other economic development areas through their inner system or PSBC. Such kinds of activities cause massive countryside's deposit outflow, and created difficulties in financing rural areas. Consequently, some farmers, rural enterprises were forced to borrow the high interest rate bearing loan from local people to meet their financial needs.

By the end of 2007, there were 40813 villages and townships in China and 2868 villages and townships were out of any banking and financial institutions outlet (Table 1). Nearly 7 percent villages and townships were unbanked in the end of 2007. The number of unbanked villages and township were 2792 in the end of 2009 and 2312 in the end of 2010. Between 2009 and 2011, 1096 unbanked villages and townships were eliminated, among them 616 were eliminated in 2011. Data shows that, still 1696 viz. 4.19 percent villages and townships did not have any banking and financial institutions outlets by the end of 2011. The portion of unbanked village and townships significantly decreased 5 years period between 2007 and 2011. This improvement is significant though it is not satisfactory and still there are challenges for Chinese government and authorities to eliminate all the unbanked areas in China.

Table 1. Number of unbanked villages and townships

\begin{tabular}{lccccc}
\hline \multicolumn{1}{c}{ Villages and Townships } & $\mathbf{2 0 0 7}$ & $\mathbf{2 0 0 8}$ & $\mathbf{2 0 0 9}$ & $\mathbf{2 0 1 0}$ & $\mathbf{2 0 1 1}$ \\
\hline 1. Total Number* & 40813 & 40828 & 40858 & 40906 & 40466 \\
2. Unbanked/without banking institutions & $2868^{* *}$ & NA & $2792^{* * *}$ & $2312^{* * *}$ & $1696^{* * *}$ \\
$\begin{array}{l}\text { Proportion of unbanked Villages and } \\
\text { Townships (\%) }\end{array}$ & 7.03 & - & 6.83 & 5.65 & 4.19 \\
\hline
\end{tabular}

\author{
Source: * National Bureau of Statistics of China, 2011 \\ ** CBRC, 2007a \\ *** CBRC, 2009, 2010, 2011 \\ NA: Not Available
}

Rural households are highly dependent upon informal credit channels to meet credit demand. In rural China, 67 percent of farmers' borrowed via informal channels such as relatives, friends, neighbours, underground lenders and other non-regular financial channel $(\mathrm{Xu}, 2008)$. Generally, informal credit has usury nature and high financial risk too. Because of the unavailability of formal financial institutions and the lack of credit fund in rural areas, people needed to shift to informal channels to meet their financial needs.

Issues related with the 'San Nong' are still top priorities in China. The government is giving more emphasis on this issue and urging concerned authorities to invest more in this sector. In order to solve the problems in rural financing, the authorities (CBRC, Ministry of Finance and PBOC) have introduced different policies such as the establishment of mutual-aid financial aid projects, the introduction of new-type rural financial institutions, the establishment of banking networks in rural areas and less developed regions. In this regard, the authorities have been encouraging to commercial banks, city banks to establish more VTBs, with priority given to the Western region and the underdeveloped areas in the Central region. Likewise, according to 'Linking the Eastern Region with the West Region' strategy, the big banks and well established financial institutions from the Eastern region are also encouraging to set up VTBs in economically poor Western region of China. Meanwhile, CBRC urged VTBs to serve 'San Nong' sector following the principle of 'granting small loans to diversified small borrowers'. 
New-type rural financial institutions have been playing an increasingly important role in promoting the development of rural finance, and they have been taking a crucial part in solving the problems such as the low level of agricultural modernization, and the farmers' financing difficulties (Liu and Yuan, 2012). The establishment of new-type rural financial institutions is a new concept of providing rural financial services in the rural sector.

\section{Policy Adjustment to Deepen Rural Financial Market in China}

In December 20, 2006, the CBRC released a policy paper number 90 titled "Opinion Regarding Easing Market Access for Banking Financial Institutions in Rural Areas in order to better Support the Construction of a New Socialist Countryside". This policy stressed on two major issues related with the rural financial institution admittance policy i.e., Capital liberalization and Institutional liberalization.

In the Institutional liberalization sector, the above policy advocated the creation of three new-types of rural financial institutions viz. VTBs, Lending Companies (Here after LCs), and Rural Mutual Credit Cooperatives (Here after RMCC), to support commercial banks and rural cooperative banks to set up the branch offices in the rural area, in order to effectively support the socialist new countryside construction.

In the Capital liberalization sector, a "Low threshold, strict supervision" principle has been adopted. The policy allows all types of social capital, banking capital, industrial capital and private capital from domestic and abroad, to be invested in rural financial market. It is permitted to have ownership and restructure the current financial institutions in rural areas, especially the RCCs.

The policy lowered the registered capital threshold of RMB 3 million $(\$ 384,615)$ for the county (City) bank, RMB 1 million $(\$ 128,200)$ for the VTBs, and RMB 300,000 $(\$ 38,462)$ for township mutual-help associations, as well as RMB 100,000 $(\$ 12,820)$ for village mutual-help associations. For initial establishment of a rural bank, there must be one domestic financial institution or bank as an initiator or contributor (Guo and Jia, 2009). According to the policy registered capital needed to establish county based VTBs is RMB 3 million and RMB 1 million for township based VTBs. Lowering the required registered capital to establish VTBs was also a positive step taken by CBRC, which created favourable and encouraging environment to run more VTBs in China.

The policy adjustment is a landmark phase in deepening rural financial market in China. As a result, many VTBs are established to broaden the financial services in the rural China.

\section{The Development of Village and Township Banks in China}

The main purpose of establishment of VTBs is to provide financial services to promote the development of local agriculture and rural economy. The VTB is an independent legal entity that enjoys the entire property of the entity that is formed by the investments of its shareholders (CBA, 2011). It is a joint-stock Bank with clear and diversified ownership structure. As per its objective, it only provides financial services to the local borrowers, mainly to local farmers, agricultural production and rural area.

The policy (Several Opinions on Adjusting and relaxing the Access Policies for Banking financial Institutions and Better supporting the Construction of new Socialist Countryside) released by CBRC in December 2006, aims at easing the market access for financial institutions in less-developed rural areas. Jilin, Sichuan, Inner Mongolia, Gansu, Hubei and Qinghai were selected as six pilot provinces (and autonomous regions). In the beginning phase, 31 new-type financial institutions viz. 19 VTBs, 4 LCs and 8 RMCCs were established in 2007.

On March 2007, Huimin Rural Bank in Yilong County, Sichuan Province started its operation as the first VTB in China (CBRC, 2009). In September 2007, the CBRC decided to enlarge the number of pilot units from six provinces (autonomous regions) to all the provinces (autonomous regions) of China except Beijing, Tianjin, and Shanghai municipality (CBA, 2011). Since 2007, commercial banks are allowed to establish its own village bank in the form of sole proprietorship or joint stock partnership with either individual and/or institutional investors. This relaxing policy motivated many commercial banks to operate VTBs in rural China. Since the year 2008 the speed of establishment of new type financial institutions were taken up. As a result, number of VTBs were remarkably increased and stood as 91 in end of 2008 from 19 in end of 2007 (Table 2). 
Table 2. The establishment of new-type rural financial institutions (operational)

\begin{tabular}{lccccc}
\hline New-type Rural Financial Institutions & $\begin{array}{c}\text { As end of } \\
\mathbf{2 0 1 1}\end{array}$ & $\begin{array}{c}\text { As end of } \\
\mathbf{2 0 1 0}\end{array}$ & $\begin{array}{c}\text { As end of } \\
\mathbf{2 0 0 9}\end{array}$ & $\begin{array}{c}\text { As end of } \\
\mathbf{2 0 0 8}\end{array}$ & $\begin{array}{c}\text { As end of } \\
\mathbf{2 0 0 7}\end{array}$ \\
\hline 1. Village and Township Banks & $726^{*}$ & 349 & 148 & 91 & 19 \\
2. Lending Companies & 10 & 9 & 8 & 6 & 4 \\
3. Rural Mutual Credit Cooperatives & $50^{* *}$ & 37 & 16 & 10 & 8 \\
$\quad$ Total & $\mathbf{7 8 6}$ & $\mathbf{3 9 5}$ & $\mathbf{1 7 2}$ & $\mathbf{1 0 7}$ & $\mathbf{3 1}$ \\
\hline
\end{tabular}

Source: CBRC, 2007b, 2008, 2009, 2010, 2011

Note: * 726 VTBs (of which 635 already commenced operation)

** 50 RMCC (of which 46 already commenced operation)

In June 2009, CBRC issued provisional rules on transformation of Micro-credit Companies (MCCs) into VTBs. This movement indicated that VTBs became the main part of the rural financial institution reform. In 2009, the pilot program of promoting new-type rural financial institutions showed some progress and 'The General Working Plan for New-type Rural Financial Institutions (2009-2011)' was drafted and planned to establish, additional 1,294 new type financial institutions including 1,027 VTBs with the priority given to the under-banked regions in Central and Western China by the end of 2011. The plan further expected that the new rural financial institutions will supplement the existing institutions to accomplish the 'inclusive finance' in rural China between 2009 and 2011 years. As a result, the number of established new-type financial institutions rapidly increased and the number reached 172 and 395 in 2009 and 2010, respectively.

In 2011, the CBRC issued the Notice on "Adjusting Licensing Policies and Procedures for the Establishment of Village and Township Banks", urges to efficient development and effective management of VTBs. Furthermore CBRC encouraged to various initiating banks for establishing more VTBs giving priority to the Western region and the underdeveloped county areas in the Central region. By the end of 2011, a total of 786 new-type rural financial institutions were incorporated. The number of VTBs increased remarkably, though only 70.7 percent goal of "Three year 2009-2011 rural financial plan" was achieved. A total of 726 VTBs were incorporated by the end of 2011. Nine different types of financial institutions viz. state owned large commercial banks, policy banks, joint-stock commercial banks, city commercial banks, rural commercial banks, rural cooperative banks, urban credit cooperatives, RCCs and foreign banks have individually and jointly founded these VTBs. Among those VTBs, 635 had started formal operation while the remaining ones were busy in making preparations for establishment. The figure was only 19 by the end of year 2007. From the above data, it is clear that the VTBs have been promoted and has become an important mechanism to increase financial inclusion and reduce unbanked rural areas in China.

\section{Total Capital, Deposits of New-Type Rural Financial Institutions}

As mentioned above, new-type rural financial institutions in China consist of three type of financial institutions viz. VTBs, LCs and RMCC. The new-type of rural financial institutions collected 4.12 billion RMB of total equity capital in the year 2008 (Table 3). Equity capital of new-type rural financial institutions reached at RMB 7 billion in 2009 and RMB 17.38 billion in 2010. At the end of 2011, collected total equity capital was RMB 36.9 billion which was more than 2 times greater than the previous year and 8 times greater than the year 2008 . 
Table 3. Total capital, deposits and loans amount of new-type rural financial institutions

Unit: $R M B$ in billion

\begin{tabular}{lccccc}
\hline \multicolumn{1}{c}{ Heading } & $\begin{array}{c}\text { As end of } \\
\mathbf{2 0 0 8 *}\end{array}$ & $\begin{array}{c}\text { As end of } \\
\mathbf{2 0 0 9 *}\end{array}$ & $\begin{array}{c}\text { As end } \\
\text { of 2010* }\end{array}$ & $\begin{array}{c}\text { As end of } \\
\mathbf{2 0 1 1} * *\end{array}$ & $\begin{array}{c}\text { Progress/Increase } \\
\text { (2008 to 2011) }\end{array}$ \\
\hline 1. Equity Capital & 4.12 & 7 & 17.38 & 36.9 & by 8 times \\
2. Total Deposit & 6.46 & 26.9 & 75.27 & 100.67 & by 15 times \\
3. Outstanding balance of loan & 3.42 & 18.1 & 60.09 & 131.6 & by 37 times \\
a. Total Loan to Rural & 3.27 & 15.7 & 50.59 & 105.2 & by 31 times \\
$\quad$ household and small business & $(96 \%)$ & $(87 \%)$ & $(87 \%)$ & $(80 \%)$ & \\
Rural household loan & 1.39 & 6.6 & 20.32 & 43.2 & by 30 times \\
& $(41 \%)$ & $(37 \%)$ & $(34 \%)$ & $(41 \%)$ & \\
Small business loan & 1.88 & 9.1 & 30.27 & 62 & by 32 times \\
& $(55 \%)$ & $(50 \%)$ & $(66 \%)$ & $(59 \%)$ & \\
b. Other loan & 0.15 & 2.4 & 9.5 & 26.4 & by 175 times \\
& $(4 \%)$ & $(13 \%)$ & $(13 \%)$ & $(20 \%)$ & \\
\hline
\end{tabular}

Source: * Development Research Center of the State Council. 2008, 2011

Note: ${ }^{* *}$ The figure in (\%) refers to portion of specific loan heading to total loan disbursement.

New-type rural financial institutions have collected RMB 6.46 billion amounts of total deposits in the year 2008; it was reached at RMB 26.9 billion in 2009, RMB 75.27 billion in 2010 and RMB 100.67 billion in 2011. By the end of 2011, total deposit collection increased by 15 folds compared to the year 2008 .

In the loan distribution sector, total outstanding loans amount was only RMB 3.42 billion in the year 2008. It stood at RMB 18.1 billion in 2009, RMB 60.09 billion in 2010 and RMB 131.6 billion in 2011. The data proves that loan distribution capacity of new-type rural financial institutions has increased remarkably. By the end of year 2011 the loan distribution amount has increased by 37 times of the year 2008 .

The huge portion of loan had been distributed to rural farmers and small business enterprises. In the year 2011, 80 percentage of the loan was distributed to rural farmers and small business enterprises. It was 96 percentage in the year 2008 and 87 percentage in both the year 2009 and 2010. The direct loan to rural household and small business stood at 41 percentage and 59 percentages respectively in the year 2011. The portion of other loan was increasing, while the loan to rural farmers and small enterprise was decreasing year by year. In the beginning phase of new-type financial institutions, almost the maximum proportion of loan (96\%) was distributed to the rural household and small business in 2008 but it decreased to 80 percent in the year 2011 .

In China, agriculture-related loans distributed by all financial institutions reached RMB 11.77 trillion by the end of 2010 (PBOC, 2011a). Meantime, new-type rural financial institutions loans distribution was RMB 60.09 billion which was only 0.51 percent of total agriculture- related loans distributed by all financial institutions. It shows that new-type rural financial institutions' contribution is still in very tiny amount compared to national level agriculture related loans.

During the period of 2008 and 2011 the deposit collection increased by only 15 times whereas loan disbursement increased by 37 times at the same period. It can be concluded that the deposit collection capacity of new-type rural financial institutions is comparatively weaker than the loan distribution. These institutions should enhance the capacity to collect more deposit from the local people and for that financial innovation and different financial products should be design to attract more deposits from the rural people. Instead of having many difficulties and challenges, new-type rural financial institutions are gradually playing significant role in rural financial market through providing financial services in the rural and unbanked areas. 


\section{Existing General Problems in Rural Finance}

\subsection{Higher Risk in Agriculture Sector}

Agricultural output is more depends upon the natural condition and weather. Farmers have fear of natural disaster risk and market risk. Agriculture output market is highly volatile and flexible in nature. The farmers may not get the reasonable price of agricultural products. Sometimes they are compelled to sale the products below the cost price. Rural farmers hardly get direct contact with the actual consumers due to geographical distance. So, farmers have lack of confidence in repaying the debt and will not go for credit. Due to higher risks inherent in agriculture sector, many financial institutions/investors are not willing to enter to rural finance.

\subsection{The Problem of High Interest Rate}

According to China's Supreme Court judicial interpretations; the interest rate which is four times higher than the legal interest rate is known as usury and it cannot be protected by the law. According to China's current loans policy, the annual interest rate is $6 \%$ (PBOC, 2011b), so maximum annual interest rate that can be set up to around $24 \%$ in small farmer loan. Within this interest rate criterion, rural financial institutions can easily operate their business in commercial way. Research shows that rural financial institutions are charging higher interest rate in small farmer loan and $85 \%$ of small farmer loans carry upper limit interest rate viz. around $24 \%$. It is hard to afford higher interest rate bearing small farmer loans for rural farmers.

\subsection{Deprivation of Rural Household from Subsidized and Low Interest Bearing Loan}

Low interest rate and interest free poverty alleviation loan are basically for local government's industrial projects. But these kinds of low interest rate bearing loan and interest free loan (subsidized loans) in agricultural development are mostly enjoyed by elite family from countryside, high official persons, village party leaders and cadres etc. (Sun, 2008). The subsidized and soft loans are illegally taken possession by the elite family following the wrong approaches with the help of power and influence. So, rural impoverished community generally could not get opportunity to take credit from the rural financial institutions. For many rural farmers the key-point is not the issue of higher interest rate but the problem of getting loan.

\subsection{Existence of Underground Finance}

Comparatively, the interest rate of Small farmers' loan and usury in village is not too high. In many rural areas, people think that 'Tai Qian' (means 'Carry Money' which refers to folk usury) is the only way of rapid financing. Generally, the 'Tai Qian' interest rate is several times greater than bank's interest rate, and it has nearly ten times greater credit risk, but only few people care about it (Sun, 2008). Recently, China's underground financial scale has developed considerably. The main reason is that the reform of the financial system has become the bottleneck of economic growth. On the one hand, some underground financial activities have clearly "usury" in nature. On the other hand, the underground finance is satisfying farmer's credit demand, financing the private enterprises but it is beyond control of regulatory authorities. At present, formal and underground two financial operations exist in China. Such existence shows that the China's financial dislocation is comparatively serious and underground financing should be regularized into formal financial system.

\subsection{High Operating Cost Inherent in Microcredit Service Provider}

According to the World Bank data, internationally commercialized sustainable microfinance institutions (MFIs) management cost is approximately $10 \%$ to $15 \%$. China's financing cost is comparatively low with direct deposit; whole sale funding cost is $6 \%$, if the money is borrowed from market the cost is nearly $7 \%$ to $8 \%$. In addition provision of bad loans is at least around $2 \%$ to $3 \%$ of total loan amount, so that the cost of each loan is above $18 \%$ (Ling and $\mathrm{Xu}, 2006$ ). The loan officer/staff have reached the microcredit needy people's home which causes transaction cost generally high. The main reason microcredit interest rates are higher than those of other financial institutions is the high operating cost to deliver small loans- paying administrative and staff expenses. It is hard to sustain microcredit lending institutions without higher interest rates. In Bangladesh the government has capped the annual interest rate that MFIs can charges is at 27\% (The Economist, 2010). Though there is the issue of capping interest rate by government, some researchers suggest that restricting people's access to microcredit by capping rates could have the perverse effect of driving more poor people into the arms of village loan-sharks, who still provide the bulk of rural credit in poor countries.

Besides above mentioned problems, the fund outflow from rural financial market by state-owned commercial banks and the postal saving banks, weak demand by farmer households due to low income, inadequate banking networks, slow growth of agricultural related loans, lack of modern financial services and backward agricultural insurance policy are still in existence in rural financing in China. 


\section{Specific Problems in the Developments of VTBs}

\subsection{Lack of Enthusiasm to Initiate VTBs in Some Initiating Banks}

China's top five banks viz. ICBC, ABC, Bank of Communications (BOCm), CCB and BOC each opened 2, 4, 3 , 16 and 18 VTBs respectively by December 31,2011, compared to the total of 85 VTBs opened by 13 of the 16 listed lenders. By contrast, small and medium sized lenders, especially Rural Commercial Banks, grew fast in the field (Big Lenders, 2012). The 'Research on the Development of VTBs in China' jointly conducted by CBA, 2011 and Working Group of Inclusive Finance in China, October 2011 shows that among 192 VTBs, City Commercial Banks, Rural Cooperative Banks and Rural Commercial Banks initiated $45 \%, 14 \%$ and $13 \%$ of total respectively whereas large state owned banks and joint-stock banks accounted for only $6 \%$ each. These above information clearly show the lack of enthusiasm to initiate VTBs by large scale state owned banks and joint-stock banks. These commercial and joint stock banks are operating in huge scale and transaction with large branch network and outlets. The VTBs operation could not have positive influence in their overall business. Many large banks are only fulfilling the necessary requirements of banking regulatory authorities due to the inherent risk in VTBs and rural finance.

\subsection{Local Government Intervention}

Some local governments have put forward local policies to the VTBs and impose income tax and business tax as local government's requirements. In some provinces it has been observed that the local governments have been intervening in daily business operation of VTBs; being stock holder, creating restrictions in expansion of business and determining the floating rate between deposit interest rate and lending interest rate. In contrast, some local governments have not taken necessary actions to promote and deploy investment in VTBs with fear of intervention. This investment gap condition attracted large scale private investment and which created misconception among rural people towards VTBs as "Private Bank". Due to misconception of "Private Bank" people hardly trust on VTBs which negatively affects in the collection of deposit as well as market expansion. Local government role in promotion and development of the VTBs is necessary. Local government's roles such as to keep check and balance between private and public shareholders, to build effective bank credit system are required though it may create the serious problem of intervention in the VTBs. Moreover, local government's intervention in loan disbursement procedure will lead to VTBs' dissimilation; this is the profound lessons of China's RCCs development. So it is required to make business friendly and supportive environment to ensure sustainable development of the VTBs.

\subsection{Impracticable Government Tax and Interest Rate Policy}

Generally, in China, the credit between RMB 50000 to 200000 amount is treated as microcredit by financial institutions (Zhao et al., 2011) but according to government tax policy, business tax is exempted for interest revenue up to RMB 50000 microcredit and small farmer loan (Cai Shui 2010). The tax exemption policy is just as a showcase for the VTBs. If the loan amount size is decreased, farmers and small enterprises could not meet their financial need and rural people are compelled to divert commercial banks or local lenders. Due to crossing the exemption limit the VTBs should pay heavy tax amount to the government. So this kind of impracticable tax policy should be changed to promote the VTBs. Meanwhile, government interest rate cap policy, high operating cost, low interest rate, and lack of risk compensation system are adding problems in financial sustainable development of VTBs.

\subsection{Lack of Access in Advanced Technology}

Currently, VTBs do not have internet banking system for its customer. The VTBs do not have access to China Union Pay system and are facing restrictions in launching electronic bank card. Still, VTBs are not allowed to enter the interbank lending market. In this modern banking era, it is required to introduce and adopt modern and advanced banking technology to facilitate its customer effectively. So, the lack of access in advanced technology is also the reason of losing people's attraction in VTBs.

Likewise, the control on VTBs by large shareholders or traditional commercial banks, slow progress of set up new VTBs, loan disbursement only in counties, and difficulty in collecting deposits, lack of skilled and professional human resources are still the problems of VTBs development.

\section{Supporting Measures for Development of the VTBs}

\subsection{Institutional Arrangement}

To develop VTBs, it is necessary to start loan officer incentive mechanism. Firstly, the loan officer should professionally train local farmers. Instead of basic salary loan officer should get some monetary incentive from 
every loan interest income. Secondly, the membership upgrade incentive mechanism should be formed where the level of members can be determined on the basis of their work performance. The great amount of loan and incentive can be enjoyed by the high level members. The loan amount limitation for different borrower's level/grade should be determined on the basis of financial need and capacity of targeted borrower as well as organizational target and capacity. The institutional supervision and management should be kept effective and competitive. The regular supervision and competitive management body could lead the organization to success. The approval, release and repayment condition and trend of loan should be frequently monitored by supervisory body which effectively control the credit risk and rectify the error in time.

\subsection{Government Role}

The government support and assistance is the next supporting measures for developing VTBs. Special subsidies should be given to VTBs. The rural financial sector is suffering from low credit fund. So the problem of source of credit funds should be solved, since the demand of short term loan is comparatively higher in rural sector. Refinancing should be expanded through the central bank and the market mechanism from the Postal Savings Banks interbank lending. By reducing the institutional tax and income tax can also enhance the small farmers' friendly environment. The reduction of business tax and income tax in VTBs decreases the heavy tax burden and attract new investment in comparatively low tax area. Furthermore, the government and concerned authorities' efforts should be made to improve the brand image and public credibility of VTBs. Local government can act as a guardian to extend the financial services in the rural areas. Local government's leading role in communication and cooperation is required rather than intervention in autonomous operation of VTBs. Likewise, government should change the impracticable fiscal and operational rules and regulation. Advanced and practical rules and regulations could create supportive environment to flourish VTBs.

\subsection{Cooperation with Other Rural Financial Institutions}

In China's rural financial market, four different kinds of financial institutions are providing financial services in their own way. Besides policy based ADBC and commercial banks, other cooperative based and new-type financial institutions are competing in the rural financial market. Healthy competition and cooperation between these financial institutions brings the positive changes in financial inclusion of rural household. The financial cooperation between these institutions would help to meet the lack of funds in short period. It also supports in overall management and leadership of VTBs. Cooperation in information sharing on target market and clients result in institutional growth and expansion of business. Through the strengthening cooperation, VTBs should solve the backward payment/settlement system.

\subsection{Innovative Financial Products}

In order to ensure long-term sustainability and growth, VTBs should invent and design financial products which can satisfy the socio-economic needs of rural farmer. Innovation of financial products focusing on rural farmers' socio-economic needs, living standard and financial knowledge will attract new customer into VTBs. Moreover, VTBs should provide necessary financial information and management skills to handle farmer's seasonal income, extra income and risk management. It will create extra economic benefit and support the borrower.

\subsection{Deepening and Strengthening the Agricultural Insurance System}

This problem can be gradually eliminated through the deepening and strengthening the agricultural insurance system. Moreover, it can improve the repayment ability of farmers, thereby reducing the loan risk, increasing their loan enthusiasm, eliminating the lending bank's worries for the future. Through the establishment of agricultural insurance system, the government and concerned authorities should permit to operate insurance and reinsurance and the provisions of financial support to agricultural insurance product should be formulated.

\section{Conclusion}

The establishment of VTBs within new-type rural financial institutions is a useful financial mechanism to solve the problem of rural financing in general and broaden the network coverage of financial institutions and financial inclusion in particular. The VTBs are playing a positive role in rural finance through meeting the diversified financial needs in rural areas, helping to fulfil financial gap, mitigating rural fund outflow, forming the substitute for the private finance and promoting the competition in rural financial markets.

The VTBs have developed rapidly since 2008 though the number of VTBs is comparatively less than the target number in the "Three year 2009-2011 rural financial plan". The main problems in development of VTBs are the lack of enthusiasm in initiating banks to set up VTBs, local government intervention, impracticable government fiscal policy, lack of access in advanced banking technology, and difficulties in collecting deposit from local rural people. 
For the development of VTBs, it not only needs the government aid and assistance; but also it needs to avoid the excessive local government intervention. The intervention of the government in loan disbursement procedure can lead to village bank's dissimilation. Instead of intervention, local government should assist VTBs in accumulating client resources and explore modes of cooperation between banking institutions and enterprises and modes of cooperation between banking institutions, enterprises and local government. An autonomous function of financial institution can enhance the sustainable development of financial institutions as well as financial inclusion.

For the sustainable development of VTBs, VTBs should set up incentive system to collect deposit and disburse loan effectively and efficiently. The cooperation between VTBs and other rural financial institutions would help to meet the financing gap in short-term and it also supports in strengthening the institutional capacity of VTBs. For the VTBs to introduce innovative financial products and strengthen the agriculture insurance system, government and concerned authorities should provide conducive environment and make necessary policy arrangement. The growth and development of VTBs in China can play a significant role in Chinese rural financial market with the improvement of rural financial system and steady development of agricultural economy.

\section{References}

Big Lenders Open Less Village Banks. (2012, June 14). Retrieved from http://china-trend.com/big-lenders-open-less-village-banks.html

Cai Shui 2010. (2010). Retrieved from http://wenku.baidu.com/view/aa4693d628ea81c758f578c0.html

CBA. (2011). Research on the development of village and township banks (VTBs) in China. Working Group on Inclusive Finance in China, Beijing.

CBRC. (2007a). The China Banking Services Distribution Map. Retrived from http://www.cbrc.gov.cn/chinese/home/docView/200808075125011BBFDAFF41FF03A55504B7B800.html

CBRC. (2007b). CBRC 2007 annual report. China Banking Regulatory Commission, Beijing.

CBRC. (2008). CBRC 2008 annual report. China Banking Regulatory Commission, Beijing.

CBRC. (2009). CBRC 2009 annual report. China Banking Regulatory Commission, Beijing.

CBRC. (2010). CBRC 2010 annual report. China Banking Regulatory Commission, Beijing.

CBRC. (2011). CBRC 2011 annual report. China Banking Regulatory Commission, Beijing.

Development Research Center of the State Council. (2008). 2008 Almanac of China's Economy. Almanac of China's Economy Press, Beijing.

Development Research Center of the State Council. (2011). 2011 Almanac of China's Economy. Almanac of China's Economy Press, Beijing.

Guo P., \& Jia, X. (2009). The Structure and Reform of Rural Finance in China.China Agricultural Economic Review, 1(2), 212-226. http://dx.doi.org/10.1108/17561370910927444

Ling, H., \& Xu, K. (2006). Microfinance banks in sight. Caijing, 2, 40-42.

Liu, X., \& Yuan, Z. (2012). The Problems and Solutions of New-type Rural Financial Institutions in China. Journal of Yunnan Agricultural University, 3, 42-47.

National Bureau of Statistics of China. (2011). China Statistical Year Book 2012. Beijing: China Statistics Press.

National Bureau of Statistics of China. (2012). Income of Urban and Rural Residents in 2011. Retrieved from http://www.stats.gov.cn/english/pressrelease/t20120130_402787464.htm

PBOC. (2011a). China Rural Finance Service Report 2010 (p. 3). Beijing: China Statistics Press.

PBOC. (2011b). Monetary policy department. People's Bank of China, Beijing.

Sun, S. (2008). Research on the Sustainable Development of Rural Bank in Jilin Province. Northeast Asia Forum, $17(6), 62-65$.

The Economist. (2010, November 18). Microfinance: Leave well alone. Retrieved from http://www.economist.com/node/17522606

Xinhua Net. (2012). Income gap between urban, rural residents narrows. Retrieved from http://news.xinhuanet.com/english/china/2012-01/20/c_131371091.htm 
Xu, S. (2008, January 7). 2007 Annual Survey Report: Rural Finance Facing New Challenges. Retrieved from http://www.cs.com.cn/yh/03/200801/t20080107_1341578.htm

Zhao, F., Wang, J., \& Yang, H. (2011). Research on Government Intervention in Village Bank Development. China Securities, 2, 134-136.

\section{Appendix}

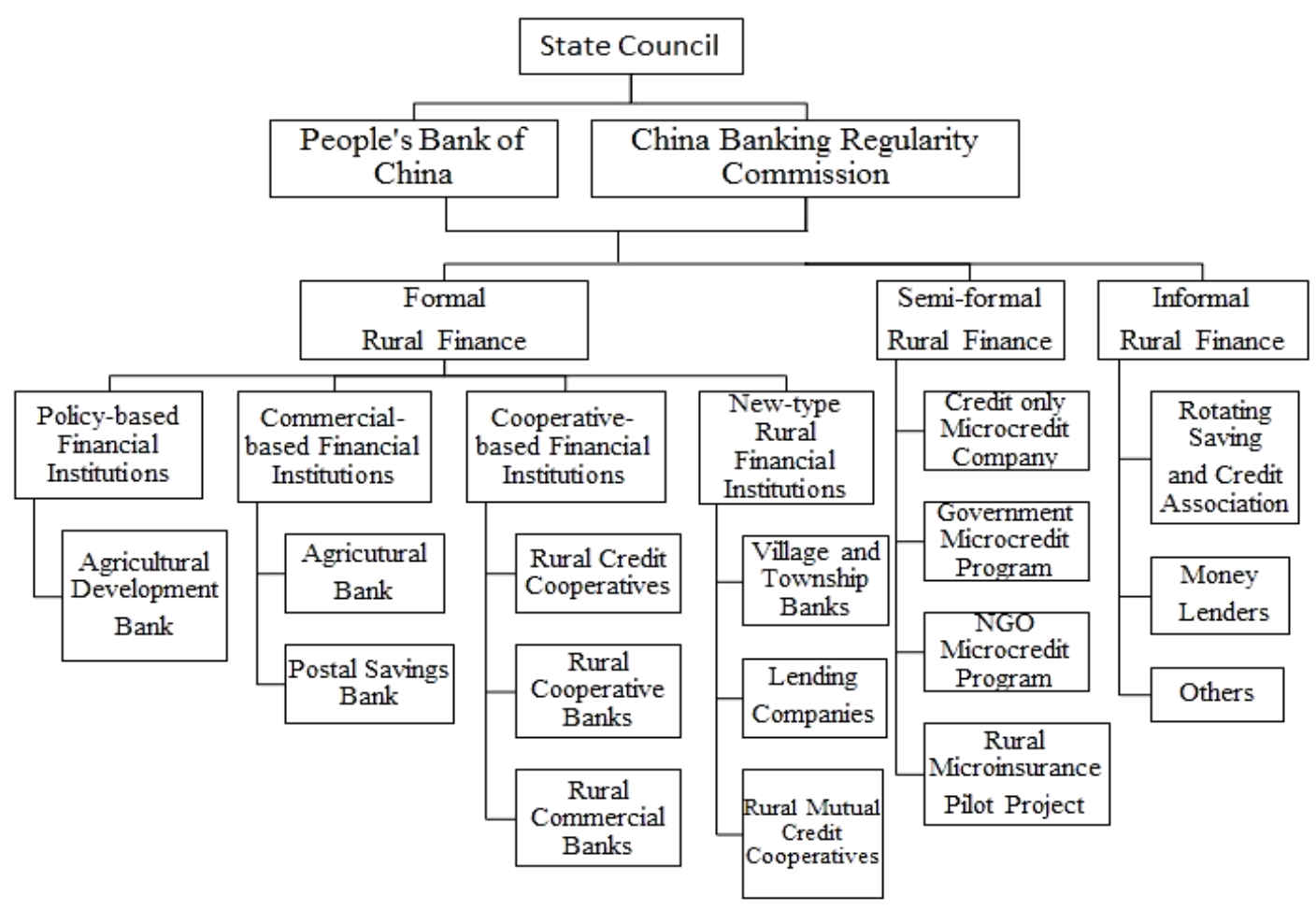

Appendix 1. Rural financial system in China

Source: Own presentation 